\title{
An analysis of morphological and molecular genetic characters for species identification of amber snails Succinea putris (Succineidae)
}

\author{
E.E. Prokhorova, R.R. Usmanova, G.L. Ataev \\ Herzen State Pedagogical University of Russia, Moyka River emb., 48, St. Petersburg, 191186
} Russia.E-mail: ataev@herzen.spb.ru

ABSTRACT: We analysed morphological and genotypic diversity of snails Succinea putris (L., 1758) collected in the north-west of Russia and in the Republic of Belarus. No significant morphological differences between snails from different populations were found. The studied snails were identical by the nucleotide sequence of ITS1-5.8S-ITS2 region of rDNA. This means that the secondary structure of the ITS 2 transcript of rDNA can be used for species identification of $S$. putris. Genetic variability based on mitochondrial markers was insignificant. Genetic distances between samples made up 0.002-0.021 for COI gene loci and 0.003-0.01 for CytB gene loci. We found ten haplotypes of the mitochondrial gene CytB and nine haplotypes of the mitochondrial gene COI. Phylogenetic reconstructions based on the obtained nucleotide sequences elucidated interrelationships between geographically distant populations of $S$. putris and confirmed the taxonomic position of this species. The genetic homogeneity of snails $S$. putris found in our study probably explains a low variability of morphological characters in this species.

How to cite this article: Prokhorova E.E., Usmanova R.R., Ataev G.L. 2020. An analysis of morphological and molecular genetic characters for species identification of amber snails Succinea putris (Succineidae) // Invert. Zool. Vol.17. No.1. P.1-17, appendices 1-3. doi: 10.15298/invertzool.17.1.01

KEY WORDS: molluscs Succinea putris, genotyping, ITS1-5.8S-ITS2, COI, CytB, morphology.

\section{Анализ морфологических и молекулярно- генетических признаков видовой идентификации моллюсков Succinea putris (Succineidae)}

\author{
Е.Е. Прохорова, Р.Р. Усманова, Г.Л. Атаев
}

Российский государственный педагогический университет им. А.И. Гериена, наб. реки Мойки, д. 48, Санкт-Петербург, 191186 Россия. E-mail: ataev@herzen.spb.ru

РЕЗЮМЕ: Выполнен анализ морфологического и генотипического разнообразия моллюсков Succinea putris (L., 1758) собранных на территории Северо-Запада России и Белоруссии. Достоверных различий по морфологическим признакам между улитками разных популяций не выявлено. Показана идентичность исследованных

Paper is dedicated to the memory of A.A. Dobrovolsky.

Статья посвящена памяти А.А. Добровольского. 
моллюсков S. putris по нуклеотидной последовательности участка ITS1-5.8S-ITS2 рДНК, а также незначительная генетическая вариабельность по митохондриальным маркерам. Это позволяет использовать вторичную структуру транскрипта ITS2 рДНК для видовой идентификации S. putris. Значения генетических дистанций между выборками для изученного участка гена СОI составляет от 0,002 до 0,021, для изученного участка гена СytB - от 0,003 до 0,01. При этом обнаружено 10 гаплотипов митохондриального гена СytB и 9 гаплотипов гена COI. C использованием полученных нуклеотидных последовательностей выполнены филогенетические реконструкции, показывающие взаимоотношение между моллюсками S. putris из разных географических популяций и подтверждающие систематическое положение этого вида. Таким образом, для изученных моллюсков $S$. putris показана генетическая однородность, которая, вероятно, и лежит в основе малой вариабельности представителей этого вида по морфологическим признакам.

Как цитировать эту статью: Prokhorova E.E., Usmanova R.R., Ataev G.L. 2020. An analysis of morphological and molecular genetic characters for species identification of amber snails Succinea putris (Succineidae)//Invert. Zool. Vol.17. No.1.P.1-17, appendices 1-3. doi: 10.15298/invertzool.17.1.01

КЛЮЧЕВЫЕ СЛОВА: моллюски Succinea putris, генотипирование, ITS1-5.8S-ITS2, $\mathrm{COI}, \mathrm{CytB}$, морфология.

\section{Introduction}

Land snails Succinea putris (L., 1758) are common in the Northern Hemisphere. First described in Europe by Linnaeus as Helix putris, they were later mentioned in the faunistic list of molluscs of France under the name of Succinea amphibia (Draparnaud, 1801). The name $S$. putris was adopted after the list of pulmonate molluscs of Great Britain was published by the Linnean Society of London (Jeffreys, 1833).

Besides their broad occurrence, amber snails are known as hosts of unique parasites, sporocysts of trematodes from the genus Leucochloridium (Ataev et al., 2016). The body of these sporocysts is represented by a stolon located in the region of the snail's hepatopancreas. The sporocyst broodsacs are filled with metacercariae. In some Leucochloridium species the broodsacs outgrow into the snail's eye tentacles. Mature broodsacs have a species-specific colour and pattern of the covers, and can pulsate, which makes them look like caterpillars. Insectivorous birds readily peck at the broodsacs and become infected with the metacercariae. This phenomenon has attracted much scientific attention, and species of Leucochloridium have been studied worldwide (Heneberg et al., 2016; Ataev et al., 2016; Prokhorova et al., 2017; Nakao et al., 2019). The best known species of the genus are L. paradoxum Carus, 1835, which has green broodsacs, and L. pertrubatum Pojmanska, 1967, whose broodsacs are brown. These two species are characterised by a low genotypic variability (Prokhorova et al., 2017; Nakao et al., 2019).

Trematodes of the genus Leucochloridium mainly parasitize Succinea putris although they have been occasionally reported from $S$. oblonga Draparnaud, 1801, S. ovalis Say, 1817, S. arenaria Potiez, Michaud, 1838, Oxyloma hirasei Pilsbry, 1901, O. retusa Lea, 1834, and some other snails (Enigk, 1932; Gower, 1936; Lewis, 1974; Pojmanska, 1978; Nakao et al., 2019). Though data on the development and biology of sporocysts of the genus Leucochloridium are scarce, it is evident that their hostparasite relationships with the snails are very specific, implying a morphological and physiological stability of the host.

The aim of our study was to assess morphological and genetic diversity of S. putris. Snails for the study were collected in Russia (Kaliningrad, Leningrad, Kirov and Moscow Regions) 
Table 1. Primers used for genotyping snails Succinea putris. Таблица 1. Праймеры, использованные для генотипирования моллюсков Succinea putris.

\begin{tabular}{|l|l|l|}
\hline Gene & \multicolumn{1}{|c|}{$\begin{array}{c}\text { Nucleotide sequences of forward (F) } \\
\text { and reverse (R) primers }\end{array}$} & \multicolumn{1}{c|}{$\begin{array}{c}\text { Annealing } \\
\text { temp., }{ }^{\circ} \mathrm{C}\end{array}$} \\
\hline 18S-ITS1-5.8 S & $\begin{array}{l}\text { F: 5' TCGGATTGGTCTCGGTCTG 3' } \\
\text { R: 5' GCGTTCAAGATGTCGATGTTC 3' }\end{array}$ & 57 \\
\hline ITS2-5.8S-28S & $\begin{array}{l}\text { F: 5' TTGCAGAACACATTGAACATCG 3' } \\
\text { R: 5' GGAGTTTACCACCCGCTTTG 3' }\end{array}$ & 57 \\
\hline CytB & $\begin{array}{l}\text { F: 5' GCATTTTTAGGTTATGTTTTACCGT 3' } \\
\text { R: 5' GGCGAATAAAAAGTATCATTCAGGT 3' }\end{array}$ & 54.3 \\
\hline COI & $\begin{array}{l}\text { F: 5' GGTCAACAAATCATAAAGATATTGG 3' } \\
\text { R: 5' TAAACTTCAGGGTGACCAAAAAATCA 3' }\end{array}$ & 56.2 \\
\hline
\end{tabular}

and in the Republic of Belarus (Vitebsk and Gomel Regions). The species of the snails was identified on the basis of morphological and molecular genetic characters.

\section{Material and methods}

Snails used in this study were collected in 2011-2017 in six geographical localities: Leningrad Region $\left(59^{\circ} 24^{\prime} 42.3^{\prime \prime} \mathrm{N} 30^{\circ} 19^{\prime} 08.1^{\prime \prime} \mathrm{E}\right)$, Kirov Region $\left(58^{\circ} 47^{\prime} 13.7^{\prime \prime} \mathrm{N} 52^{\circ} 14^{\prime} 38.0^{\prime \prime} \mathrm{E}\right)$,

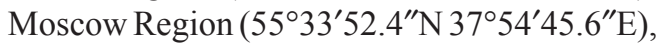
Kaliningrad Region $\left(55^{\circ} 08^{\prime} 48.9^{\prime \prime} \mathrm{N} 20^{\circ} 49^{\prime}\right.$ $\left.41.3^{\prime \prime} \mathrm{E}\right)$ of the Russian Federation and Vitebsk

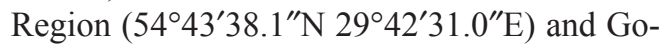
mel Region $\left(53^{\circ} 29^{\prime} 32.9^{\prime \prime} \mathrm{N} 30^{\circ} 17^{\prime} 00.8^{\prime \prime} \mathrm{E}\right)$ of the Republic of Belarus.

Morphological methods. For morphological study, snails were fixed in $70 \%$ ethanol and dissected under a Leica M165C stereomicroscope. The shell was removed, the mantle fold was cut out, and the epithelium lining the bottom of the mantle cavity was removed. Dissection proceeded in the direction of the top of the visceral sac, with the last organ dissected being the head.

Shells, radulae and jaws of the snails were dehydrated in an ascending alcohol series, goldcoated with the help of a sputter coater (Quorum Technologies SC7620) and studied under the scanning electron microscope EVO-40 (Carl Zeiss). Morphometric analysis of the shells was performed with the help of Past 3.26 software (https://folk.uio.no/ohammer/past/).
Molecular genetic analysis. Snails for molecular-genetic analysis were removed from the shell and stored at $-80^{\circ} \mathrm{C}$. DNA was extracted from each snail individually by phenol-chloroform extraction (Sambrook, Russel, 2001).

Each sample was genotyped by three molecular genetic markers: nucleotide sequence of rDNA (ITS1-5.8S-ITS2 region), mitochondrial cytochrome oxidase subunit I (COI) gene and cytochrome B (CytB) gene.

For genotyping of the rDNA region, we used primers constructed earlier for molluscs Planorbarius corneus Linnaeus, 1758 (Prokhorova et al., 2015). Primers for CytB and COI genes were chosen with the help of Primer3 software (http://primer3.ut.ee) and GeneRunner software (http://www.generunner.net) using the nucleotide sequence of Succinea putris (JN627206.1). Nucleotide sequences of the primers and operating temperatures of annealing are given in Table 1.

All PCR amplifications were performed with Taq DNA polymerase (Thermo Scientific), using $20 \mu \mathrm{l}$ reaction volume, including $15.8 \mu \mathrm{l}$ sterilized distilled water, $2 \mu \mathrm{l}$ of Taq10x buffer, $1 \mu \mathrm{l}$ of DNA $(10 \mathrm{mM}), 0.2 \mu \mathrm{l}$ of dNTPs $(2 \mathrm{mM})$, $4 \mu \mathrm{l}$ of each primer $(10 \mathrm{nM})$ and $0.2 \mu \mathrm{l}(5 \mathrm{U} / \mu \mathrm{l})$ of Taq polymerase. The fragments were amplified in a Tercyc amplifier (DNA-Technology, Russia) with an initial denaturation at $94{ }^{\circ} \mathrm{C}$ for $3 \mathrm{~min}$, followed by 35-40 cycles of denaturation at $94{ }^{\circ} \mathrm{C}$ for $30 \mathrm{~s}$, annealing for $30 \mathrm{~s}$, then elongating at $72{ }^{\circ} \mathrm{C}$ for $1 \mathrm{~min}$, with a final elongation at $72{ }^{\circ} \mathrm{C}$ for $7 \mathrm{~min}$ after the last cycle. 


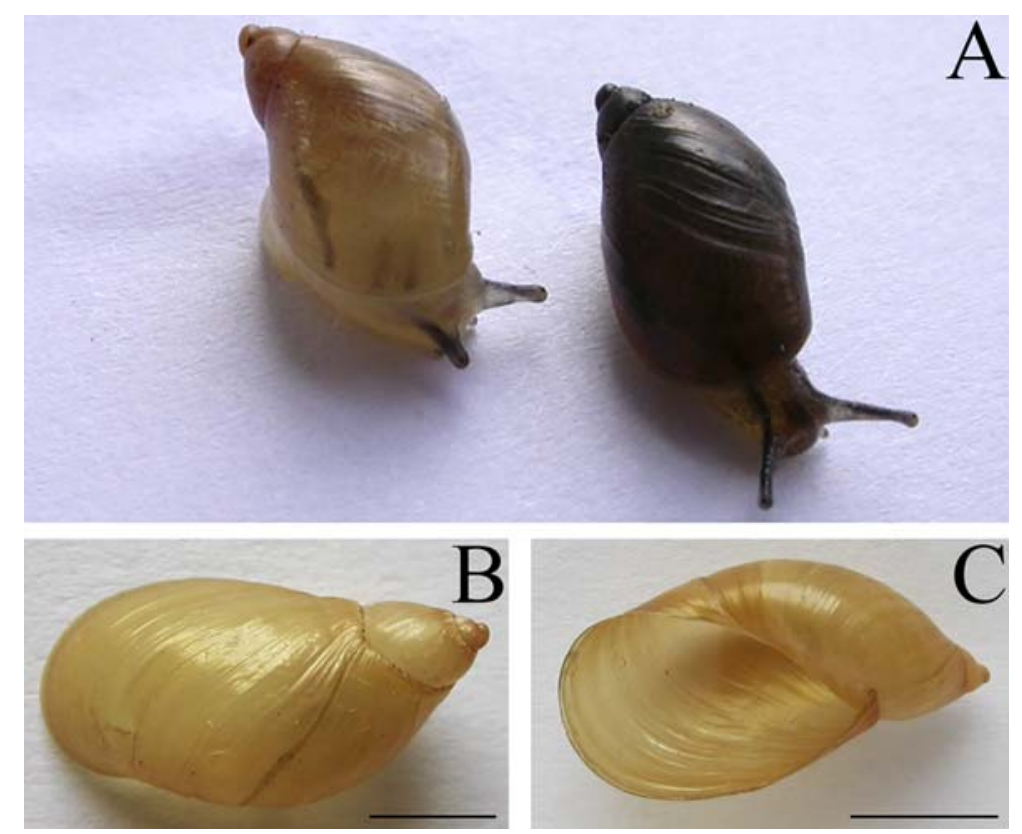

Fig. 1. External appearance and shell of snails Succinea putris. A - variation of colouration between individuals from the same population; B - shell of S. putris, dorsal view; C - shell of S. putris, ventral view. Scale bar $5 \mathrm{~mm}$.

Рис. 1. Внешний вид и раковина моллюсков Succinea putris. А 一 варианты окрасок особей внутри одной популяции; В — раковина S. putris, вид с дорзальной стороны; С — раковина S. putris, вид с вентральной стороны. Шкала 5 мм.

Electrophoretic analysis of the PCR-products was performed in $1.4 \%$ agarose gel in TBE buffer. Samples of the obtained PCR products were sequenced using an ABI PRISM 310 sequencer (AppliedBiosystems).

Assembly and multiple alignment of nucleotide sequences and analysis of the chromatograms were performed with the use of BioEdit software (http://www.mbio.ncsu.edu, Hall, 1999). To establish homology of the nucleotide sequences, BLAST software at the NCBI server was used (http://blast.ncbi.nlm.nih.gov/Blast. cgi). Specimen information and GenBank accession numbers are given in Appendix 1.

An optimal mathematical model for calculating genetic distances was chosen using Akaike information criterion (AIC) and Bayesian information criterion (BIC) with the help of $\mathrm{jMod}$ elTest 2.1.7 software (Daribba et al., 2012). The best-fitting model for ITS1-5.8S-ITS2 partition was $\mathrm{GTR}+\mathrm{I}+\mathrm{G}($ gamma $=2.2)$, for $\mathrm{COI}$ partition, $\mathrm{HKY}+\mathrm{G}($ gamma $=0.33)$, for Cyt B partition, HKY+I (Kimura, 1980, Hasegawa et al., 1985).

Mega version 7.0 software was used for maximum-likelihood phylogenetic reconstructions (Kumar et al., 2016), and for calculation of the number of variable polymorphic sites (S), nucleotide diversity per site $(\mathrm{P})$, the average number of nucleotide differences $(\mathrm{k})$, and pairwise genetic divergence ( $p$-distance).

Bayesian analyses was performed with the BEAST 2.5 software packages (Bouckaert et al., 2019). Visualisation of phylogenetic trees was performed using a graphical viewer of phylogenetic trees TreeAnnotator 1.1.4 (http://tree. bio.ed.ac.uk/software/figtree/). Bootstrap branch support (BS) levels for maximum-likelihood and Bayesian analyses were estimated with 1000 replicates (Felsenstein, 1985). The choice of the outgroups was mainly based on the presence and the completeness of nucleotide 

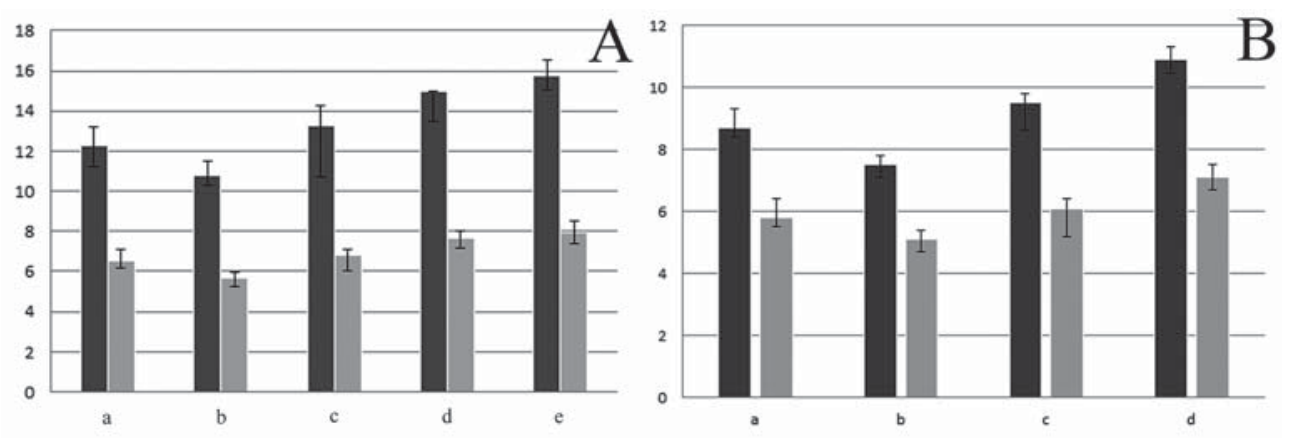

Fig. 2. Morphometric characteristics of shells of snails Succinea putris. A - shell size; B - aperture size. Designations: $\mathrm{a}-$ Moscow Region $(\mathrm{n}=25), \mathrm{b}-$ Kirov Region $(\mathrm{n}=32), \mathrm{c}-$ Leningrad Region $(\mathrm{n}=33), \mathrm{d}-$ Kaliningrad region $(\mathrm{n}=10)$, e - Vitebsk region $(\mathrm{n}=30)$. Dark grey - height, light grey - width. Median values and interquartile ranges $\left(25^{\text {th }}\right.$ and $75^{\text {th }}$ percentiles $)$ are given.

Рис. 2. Морфометрические характеристики раковины моллюсков Succinea putris. A - размер раковины; В - размер устья. Обозначения: $\mathrm{a}$ - Московская область ( $\mathrm{n}=25), \mathrm{b}$ - Кировская область $(\mathrm{n}=32), \mathrm{c}$ - Ленинградская область $(\mathrm{n}=33), \mathrm{d}-$ Калининградская область $(\mathrm{n}=10)$, е - Витебская область (n=30). Темно-серый — высота, светло-серый - ширина. Показаны медианы и интеркватильный размах $\left(25^{\Re}\right.$ и $75^{я}$ процентили).

sequences of the studied genome regions (Appendix 1).

Statistical haplotype networks were constructed using the PopArt computer program (Leigh, Bryant, 2015) with the use of median joining and TSC. Calculations of haplotype and nucleotide diversity indices were implemented using DNAsp v.6 (Rozas et al., 2017).

The folding of the sequences into putative secondary structures was performed with the help of Mfold version 3.0 (http://mfold.rit. albany.edu).

\section{Results}

Morphological analysis. The shell of snails S. putris is conispiral, dextral, ovate, thin-walled (Fig. 1A-B). The number of whorls varies from 3 to 5. The surface of embryonic whorls is covered with numerous depressions, while the surface of the following whorls bears grooves perpendicular to the columella. Most of the shell is made up by the last whorl, which opens with a large oval aperture strongly tapering near the columella.

The maximum shell size of the snails from the studied populations was $20.5 \times 11.7 \mathrm{~mm}$
(Gomel Region). The average shell size was determined for the snails from five regions: Moscow, Kirov and Leningrad, Kaliningrad Region (Russia) and Vitebsk Region (Belarus). It is shown in Fig. 2 as median values and interquartile ranges $\left(25^{\text {th }}\right.$ and $75^{\text {th }}$ percentiles $)$. Median values of the shell height of snails from the four populations mentioned above were $12.3,10.8,13.3,15.0$ and $17.8 \mathrm{~mm}$, respectively. Snails from the Leningrad Region population were characterised by the greatest variation of shell size.

Comparing the proportions of snail shells from different populations, we used the shell index (shell width: shell height) and the aperture index (aperture width: aperture height). The analysis was performed with the help of the Kruskall-Wallis test with subsequent pairwise post hoc comparison of groups with the help of Dann's test. The results indicate that shells from the Belarus population were significantly different from the other shells. We also found differences in the shell indices between snails from the Kirovsk population and snails from the Moscow population. No statistically significant differences in the aperture index were found between the populations. 


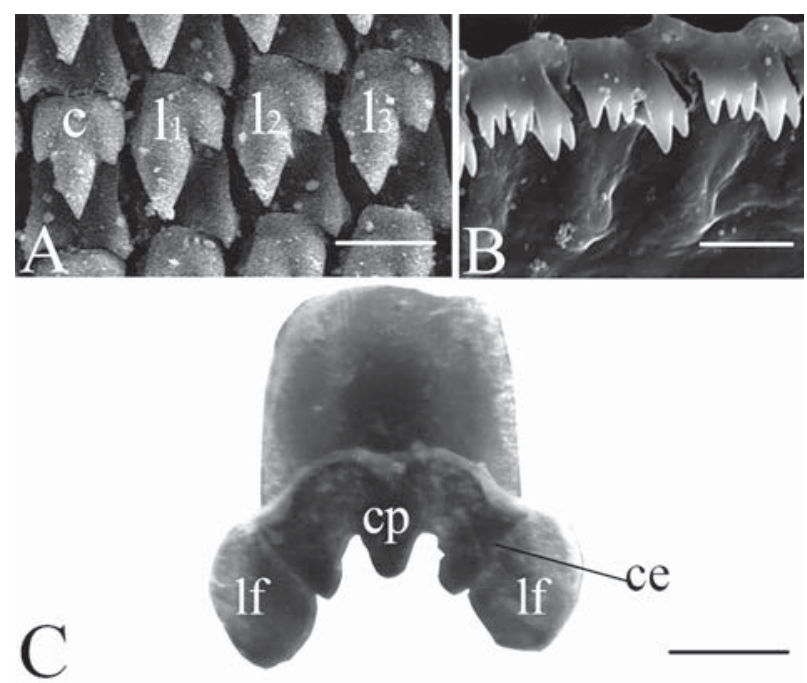

Fig. 3. Radula and jaw of Succinea putris, SEM image. A — central area of the radular ribbon; B — marginal teeth; $\mathrm{C}$ - jaw.

Abbreviations: $\mathrm{c}$ - central tooth; ce - cutting edge; $\mathrm{cp}$ - central projection; $1_{1}-\mathrm{l}_{3}$ - lateral teeth; lf - lateral fold. Scale bars: A, B $-20 \mu \mathrm{m} ; \mathrm{C}-400 \mu \mathrm{m}$.

Рис. 3. Радула и челюсть Succinea putris, изображение СЭМ. А - центральная область радулярной ленты; В - маргинальные зубы; С — челюсть.

Обозначения: с — центральный зуб; се - режущий край; ср — центральная проекция; $1_{1}-1_{3}$ - латеральные зубы радулы; If — боковая складка. Шкала: А, В - 20 мкм; С - 400 мкм.

The shells of snails from all the populations were semi-transparent, light yellowish in colour. The colouration of the snails varied from light yellow to dark brown or even black (Fig. 1) due to the differences in the pigmentation level of the surface epithelium.

The jaw of the snails was represented by a rectangular plate bearing a protrusion with an arched cutting edge (Fig. 3C). The latter bore a central projection with lateral rounded folds.

Radular formula is $22: 12: 1: 12: 22(n=3)$. The central tooth bears three cusps, the middle one being the longest (Fig. 3A, B). Lateral teeth have a large mesocone and a smaller ectocone. An underdeveloped endocone is represented by a small protrusion on the median side of the tooth. Marginal teeth are distinguished by the presence of small cusps in place of the ectocone. Differentiation into endo-, meso- and ectocone becomes indistinct towards the lateral edge of the radula.

Ovotestis, its duct and the seminal vesicle have a structure typical of the pulmonates and are located in the upper coils of the visceral sac (Fig. 4). The hermaphroditic duct opens into the carrefour, with which two receptacula seminis, lying in a depression of a massive albumen gland, are connected. The genital duct continues with a spermoviduct, the latter separating into the oviduct and the seminal duct in the area of the rounded prostate gland. The oviduct has a folded structure and becomes a short vaginal duct at the site of the joining of the duct of the receptaculum seminis.

The penis has a muscular sheath and is subdivided into the anterior, the posterior and the intercalary part. The internal epithelium of the penis has numerous grooves and papillae. The retractor attached to the penis sheath embraces the seminal duct in the distal part.

Molecular genetic analysis. We obtained nucleotide sequences of the rDNA region (1837 bp) including an 18S fragment (partly)-ITS15.8S-ITS2-28S (partly), a COI gene fragment (958 bp) and a CytB gene fragment (455 bp) of all studied snails. All the sequences of snails $S$. 


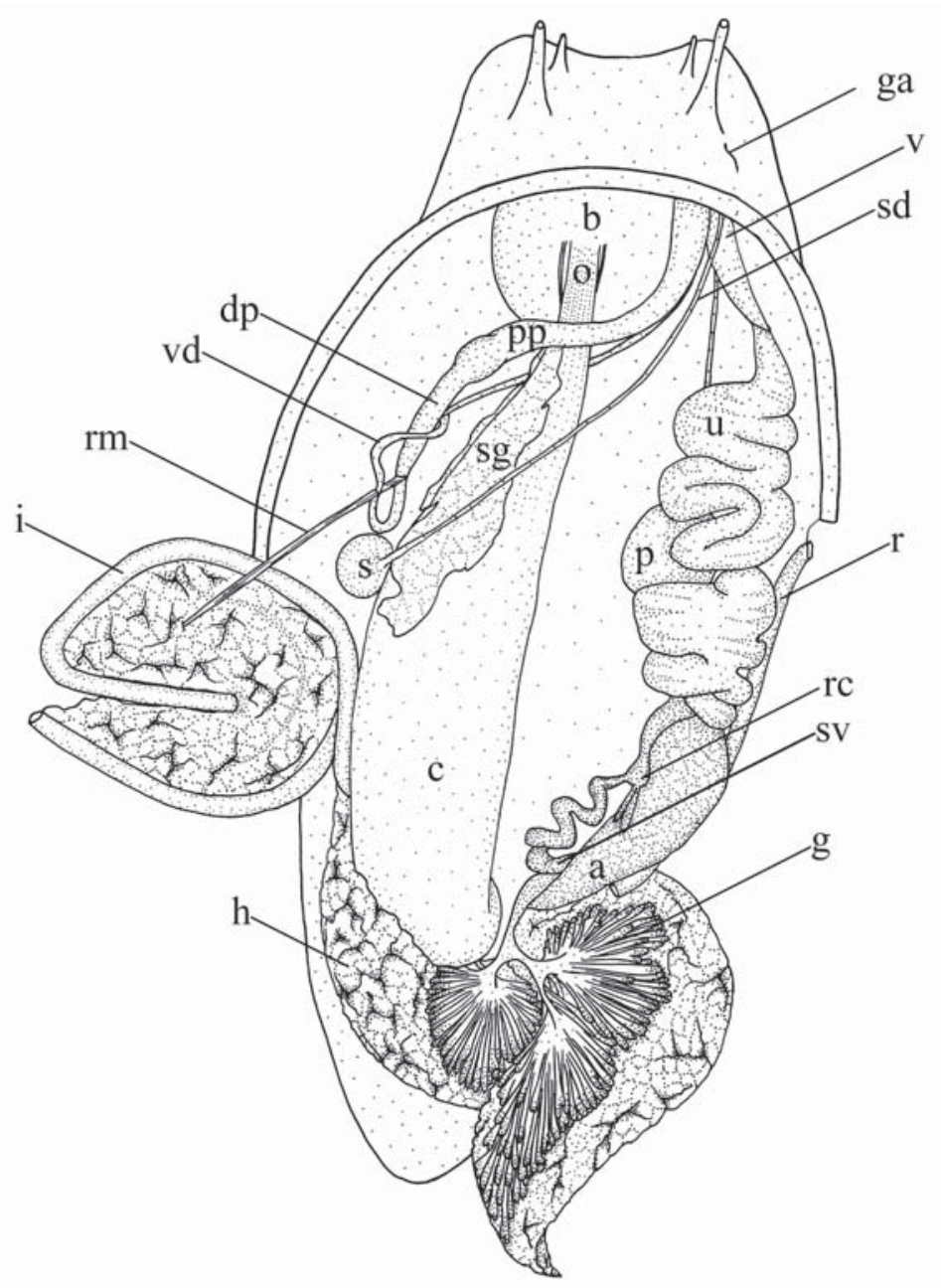

Fig. 4. General morphology of Succinea putris.

Abbreviations: a — albumen gland; b - buccal mass; c — crop; dp — distal part of penis; $\mathrm{g}$ - gonad; $\mathrm{h}$ hepatopancreas; i — intestine; o —oesophagus; pg — prostate gland; pp — proximal part of penis; $r$ — rectum; rc receptaculum complex; rm — retractor muscle; s — spermatheca; sd — spermathecal duct; sg — salivary gland; sv — seminal vesicle; u — uterus; v — vagina; vd — vas deferens.

Рис. 4. Общая морфология Succinea putris.

Сокращения: a - белковая железа; b - буккальная масса; c - зоб; dp - дистальная часть пениса; g - гонада; h - гепатопанкреас; i — кишечник; о — пищевод; pg - предстательная железа; pp —проксимальная часть пениса; r — прямая кишка; rc — комплекс семяприемника; rm - ретрактор; s — сперматека; sd — проток сперматеки; sg - слюнные железы; sv — семенной пузырек; u — матка; v — вагина; vd — семяпровод.

putris obtained in this study were deposited in GenBank, and their nucleotide composition and polymorphisms were characterised (Appendix 1, Table 2, Figs 5-10).

No intraspecies polymorphisms were found in the ITS1-5.8S-ITS2 region of rDNA in the studied snails. Homology between the nucle- otide sequences of snails from different population made up $100 \%$, indicating that the specimens belonged to the same species (Table 2). Only ITS1-5.8S-ITS2 fragment was used for the phylogenetic reconstruction based on rDNA. Nucleotide sequences of molluscs from the families Planorbidae, Bulinidae, Helicidae and 
E.E. Prokhorova et al.

Table 2. Genetic diversity of Succinea putris based on rDNA and mitochondrial sequences. Таблица 2. Генетическое разнообразие моллюсков Succinea putris по нуклеотидным последовательностям рДНК и митохондриальных генов.

\begin{tabular}{|c|c|c|c|c|c|c|c|c|c|c|}
\hline \multirow{2}{*}{ Gene } & \multirow{2}{*}{$\begin{array}{l}\text { Length of } \\
\text { sequenced } \\
\text { region }\end{array}$} & \multirow{2}{*}{$\mathrm{N}$} & \multicolumn{4}{|c|}{ Base composition (\%) } & \multirow{2}{*}{$\mathrm{H}$} & \multirow{2}{*}{$\mathrm{P}$} & \multirow{2}{*}{$\begin{array}{c}\mathrm{k} \\
(\mathrm{SE})\end{array}$} & \multirow{2}{*}{$\mathrm{S}$} \\
\hline & & & $\mathrm{T}$ & $\mathrm{C}$ & A & $\mathrm{G}$ & & & & \\
\hline ITS1 & 529 & 18 & 20.3 & 34.9 & 13.1 & 31.7 & 1 & 0 & 0 & 0 \\
\hline $5.8 \mathrm{~S}$ & 159 & 18 & 18.9 & 28.9 & 21.4 & 30.8 & 1 & 0 & 0 & 0 \\
\hline ITS2 & 710 & 18 & 19.8 & 35.0 & 14.7 & 30.4 & 1 & 0 & 0 & 0 \\
\hline $\mathrm{CO} \mathrm{I}$ & 1040 & 18 & 43.4 & 14.1 & 25.7 & 16.7 & 18 & 0.05 & 3.257 & 13 \\
\hline Cyt B & 455 & 18 & 45.7 & 13.5 & 26.5 & 14.3 & 11 & 0.002 & 1.042 & 12 \\
\hline
\end{tabular}

$\mathrm{N}$ - number of specimens (sequences); $\mathrm{H}$ - number of haplotypes; $\mathrm{P}$ - nucleotide diversity (per site); $\mathrm{k}$ - average number of nucleotide differences per sequence; $\mathrm{S}$ - number of variable polymorphic sites.

$\mathrm{N}$ - количество образцов; H - число гаплотипов; P — нуклеотидное разнообразие (на сайт); $\mathrm{k}$ - среднее различие нуклеотидных последовательностей на сайт; S - количество вариабельных полиморфных сайтов.

Bradybaenidae were used as outgroups (Appendix 1, Fig. 8). The choice of the outgroups was mainly based on the presence and the completeness of nucleotide sequences of the studied genome regions. On the phylogenetic reconstruction based on rDNA region, all the sequences of Succinea putris snails from this study grouped into the same clade and form a common branch with $S$. striata, the only closely related species genotyped by the same genome region (Fig. 8).

The interspecific differences in the ITS2 nucleotide sequences of $S$. putris and $S$. striata were visualised on topological maps of their secondary structures. Primary sequences of rRNA were transformed into putative secondary structures at the folding temperature of $20{ }^{\circ} \mathrm{C}$. The structure chosen had the highest negative free energy. The predicted secondary structures of $S$. putris and S. striata differed considerably, which was mostly due to the different length of ITS2: 529 nucleotides in $S$. putris and 545 nucleotides in S. striata. The structure of most spiral helices in ITS2 transcripts of $S$. putris and $S$. striata is similar. For instance, helix I of S. putris is identical to helix II of S. striata. Helices II, IV and V of S. putris correspond to helices I, IV and V of S. striata. They have the same nucleotide sequences at the ends and the same loops along their length. However, the number of spiral helices was five for S. putris and six for S. striata (Fig. 5). Thus, ITS2 secondary structures in these snails are noticeably different (see Discussion).

The haplotype network was constructed based on all COI and CytB nucleotide sequences of $S$. putris previously deposited in GenBank and having sufficient length for alignment with the sequences obtained in this study (Appendix 1).

Nineteen sequences were used for the construction of the haplotype network based on the sequences of CytB gene fragment (Appendix). Eighteen of them were obtained in this study, while one sequence was obtained in a study of the complete mitochondrial genome of a single S. putris specimen from France (White et al., 2011). Final alignment included 452 nucleotides and revealed 11 haplotypes. The French specimen was represented by a separate haplotype (Hap_11), situated at a considerable distance from other specimens in the haplotype network.

Two main groups of haplotypes could be distinguished in the network (Fig. 6). All the snails from Leningrad Region and Kaliningrad Region grouped together. Haplotypes of the snails from other regions were distributed between the groups. Unique haplotypes were revealed for snails from Kaliningrad Region, Leningrad Region and Moscow Region (Russia) and Gomel Region (Belarus). Average genetic distance between CytB haplotypes in the studied samples was 0.008 (Appendix 2). 

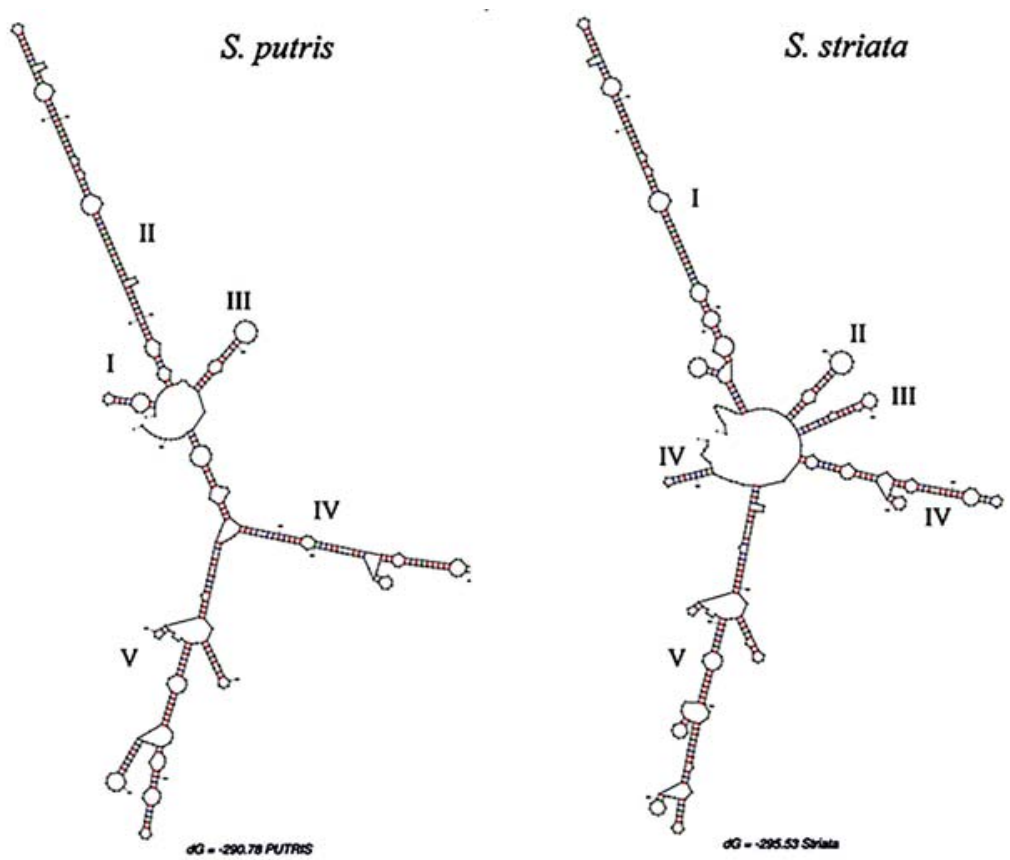

Fig. 5. Topological schemes of the secondary structures of ITS2 transcripts of Succinea striata (545 bp) and Succinea putris (529 bp). The main helices on the secondary structures are numbered starting from the 5' end. Рис. 5. Топологические схемы вторичных структур транскриптов ITS2 моллюсков Succinea striata (545 пн) и Succinea putris (529 пн). Основные шпильки на вторичных структурах пронумерованы с 5'-конца.

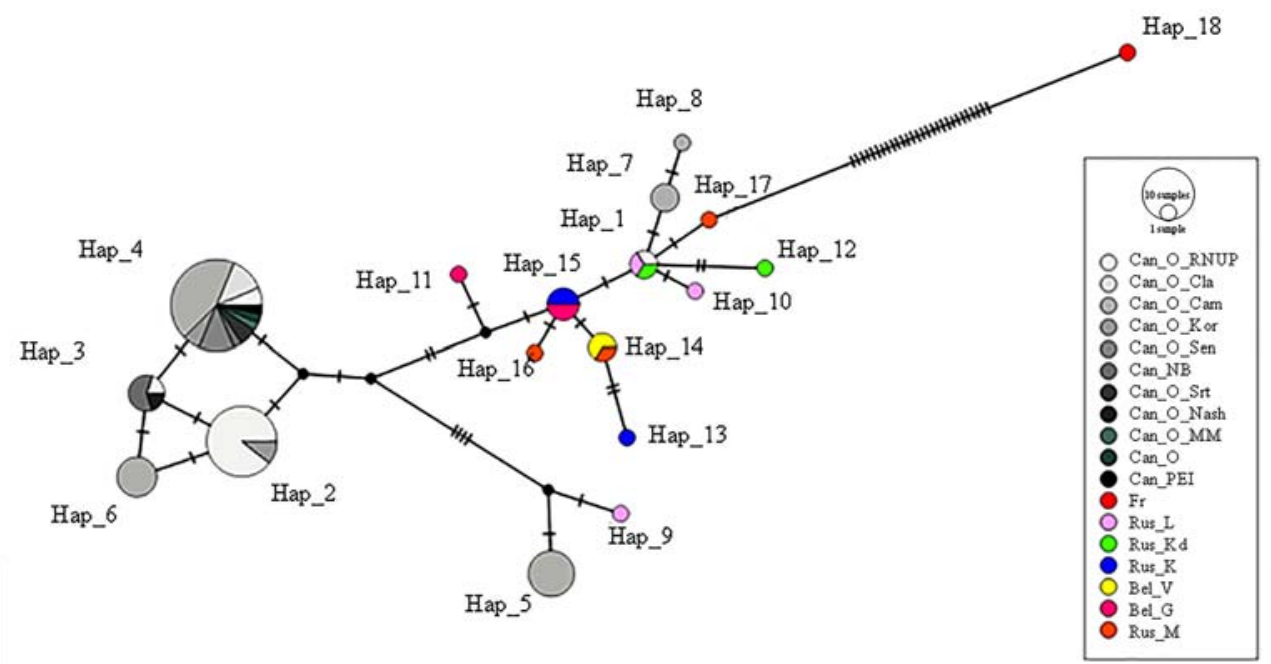

Fig. 6. Mitochondrial COI haplotype diversity of Succinea putris. For haplotype network construction sequences obtained in our research and sequences from GenBank were used. The size of circles in the network is proportional to the frequency of the haplotype. Solid circles indicate unobserved haplotypes. Every mutation is shown as one hatch mark. Colour codes reflect the population groupings (see designations). For sample codes see Table 3.

Рис. 6. Разнообразие гаплотипов гена COI моллюска Succinea putris. Для построения гаплотипической сети использованы нуклеотидные последовательности, полученные в данном исследовании, а также представленные в базе данных GenBank. Размеры окружностей в сети пропорциональны частоте встречаемости гаплотипов. Каждая мутация обозначена одним шитрихом. Различные популяции обозначены цветами (см. обозначения). Обозначения образцов представлены в таблице 3. 


\begin{tabular}{|c|c|c|c|c|c|c|c|c|c|c|c|c|c|}
\hline 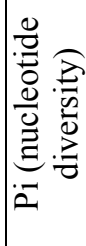 & 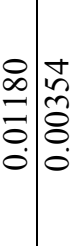 & & 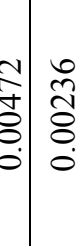 & 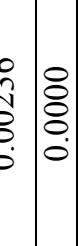 & 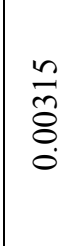 & $\mid \begin{array}{l}8 \\
8 \\
0 \\
0 \\
0\end{array}$ & $\begin{array}{l}\stackrel{1}{0} \\
\stackrel{0}{0} \\
\dot{0}\end{array}$ & 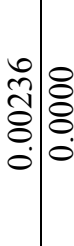 & $\begin{array}{l}\infty \\
\vdots \\
\vdots \\
\vdots \\
\vdots \\
\vdots \\
\vdots \\
0\end{array}$ & $\begin{array}{l}8 \\
8 \\
0 \\
0\end{array}$ & $\begin{array}{l}8 \\
8 \\
8 \\
0\end{array}$ & $\mid$\begin{tabular}{l|l}
$Ð$ \\
$\vdots$ \\
$\vdots$
\end{tabular} & : \\
\hline 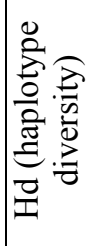 & & 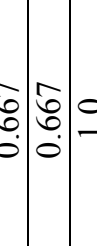 & 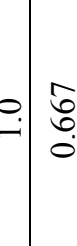 & 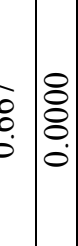 & \begin{tabular}{l}
0 \\
$\stackrel{0}{0}$ \\
\multirow{+}{*}{} \\
0
\end{tabular} & $\mid$\begin{tabular}{l}
8 \\
8 \\
8 \\
\hdashline \\
0
\end{tabular} & 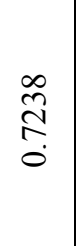 & 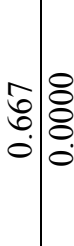 & 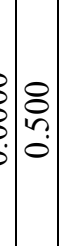 & $\begin{array}{l}0 \\
\vdots \\
0 \\
0\end{array}$ & $\begin{array}{l}8 \\
8 \\
8 \\
0\end{array}$ & 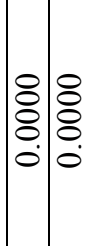 & $\mid \begin{array}{l}8 \\
8 \\
0 \\
0\end{array}$ \\
\hline 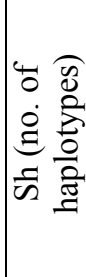 & 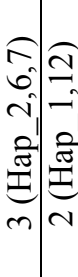 & 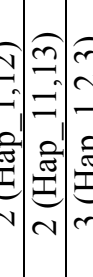 & 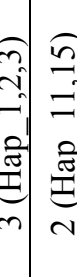 & 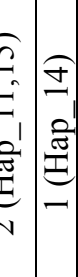 & 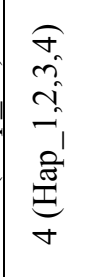 & 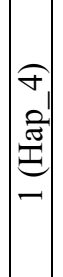 & 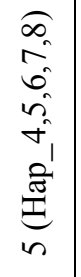 & 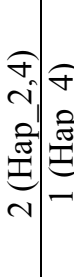 & 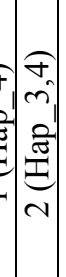 & 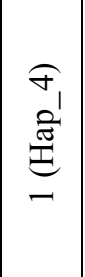 & 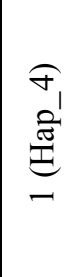 & 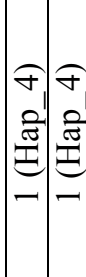 & 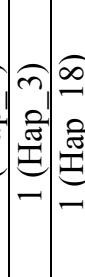 \\
\hline 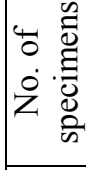 & & $n=m$ & $m m$ & $n m$ & 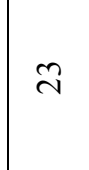 & $\nabla$ & ल & $\nabla \nabla$ & $\nabla$ & $N$ & - & $-1-$ & - \\
\hline 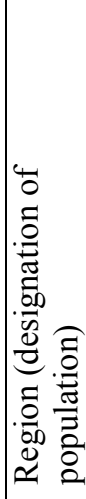 & 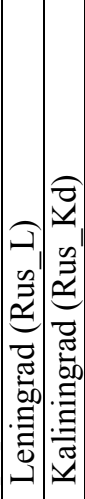 & 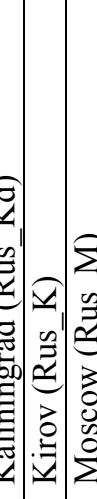 & 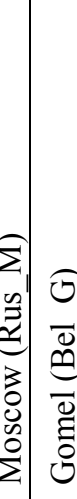 & 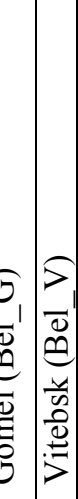 & 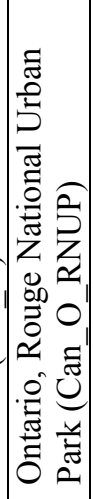 & 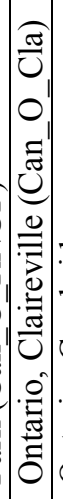 & 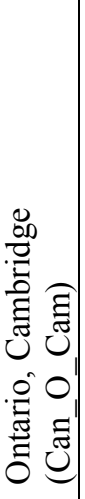 & 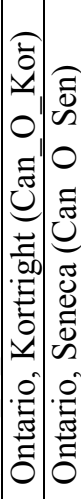 & 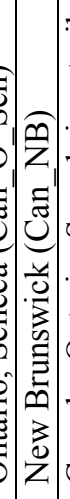 & 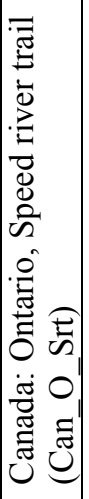 & 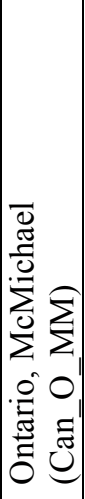 & 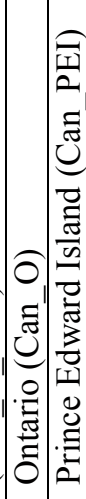 & 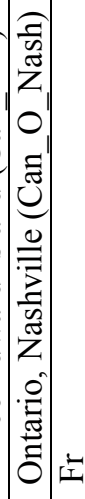 \\
\hline $\begin{array}{l}\text { E } \\
\text { ठ } \\
\text { ठ }\end{array}$ & & 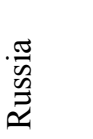 & & $\frac{\tilde{D}}{\vec{\Xi}}$ & & & & & $\begin{array}{l}\tilde{J} \\
\tilde{\Xi} \\
\tilde{J}\end{array}$ & & & & \\
\hline
\end{tabular}


Table 4. Estimates of CytB gene genetic diversity in Succinea putris within studied geographic regions. Таблица 4. Генетическое разнообразие по гену СуtB моллюсков Succinea putris в исследованных географических регионах из разных географических популяций.

\begin{tabular}{|l|c|c|c|c|c|}
\hline \multirow{3}{*}{ Country } & $\begin{array}{c}\text { Region } \\
\text { (designation of } \\
\text { population) }\end{array}$ & $\begin{array}{c}\text { No. of } \\
\text { speci- } \\
\text { mens }\end{array}$ & $\begin{array}{c}\text { Sh (no. of } \\
\text { haplotypes) }\end{array}$ & $\begin{array}{c}\text { Hd } \\
\text { (haplotype } \\
\text { diversity) }\end{array}$ & $\begin{array}{c}\text { Pi } \\
\text { (nucleotide } \\
\text { diversity) }\end{array}$ \\
\hline \multirow{4}{*}{ Russia } & Leningrad (Rus_L) & 3 & 2 (Hap_6,7) & 0.667 & 0.00737 \\
\cline { 2 - 6 } & $\begin{array}{c}\text { Kaliningrad } \\
\text { (Rus_Kd) }\end{array}$ & 3 & 1 (Hap_7) & 0 & 0 \\
\cline { 2 - 6 } & Kirov (Rus_K) & 3 & 3 (Hap_3,4,5) & 1.000 & 0.00737 \\
\cline { 2 - 6 } & Moscow (Rus_M) & 3 & 3 (Hap_1,2,3) & 1.0000 & 0.0059 \\
\hline \multirow{2}{*}{ Belarus } & Gomel (Bel_G) & 3 & 3 (Hap_8,9,10) & 1.0000 & 0.00737 \\
\cline { 2 - 6 } & Vitebsk (Bel_V) & 4 & 2 (Hap_3,8) & 0.500 & 0.00332 \\
\hline France & France (Fr) & 1 & 1 (Hap_11) & 0 & 0 \\
\hline
\end{tabular}

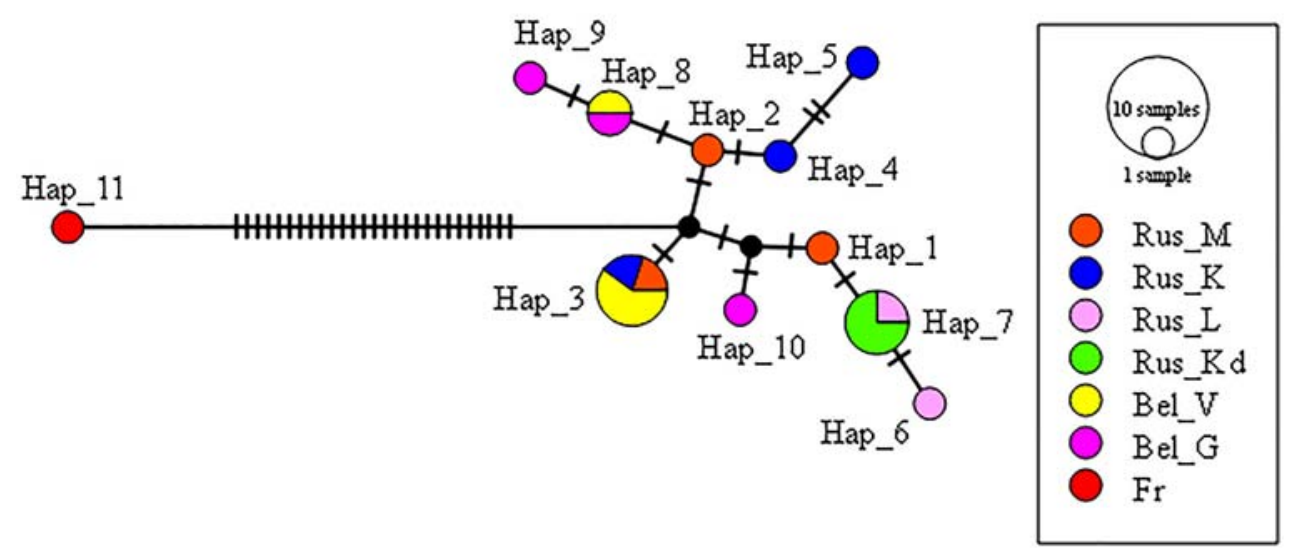

Fig. 7. Mitochondrial CytB haplotype diversity of Succinea putris. For haplotype network construction sequences obtained in our research and sequences from GenBank were used. The size of circles in the network is proportional to the frequency of the haplotype Solid circles indicate unobserved haplotypes. Every mutation is shown as one hatch mark. Colour codes reflect the population groupings (see designations). For sample codes see Table 3.

Рис. 6. Разнообразие гаплотипов гена СуtВ моллюска Succinea putris. Для построения гаплотипической сети использованы нуклеотидные последовательности, полученные в данном исследовании, а также представленные в базе данных GenBank. Размеры окружностей в сети пропорциональны частоте встречаемости гаплотипов. Каждая мутация обозначена одним шитрихом. Различные популяции обозначены цветами (см. обозначения). Обозначения образцов представлены в таблице 3.

Haplotype network of the COI gene was constructed based on 95 sequences of the COI gene fragment, 565 nucleotides in length. Most of the sequences were COI gene fragments of snails from different parts of Canada (Telfer $e t$ al., 2015). Two distinct haplotype groups, connected by only two transition haplotypes, can be seen in the network. One of the groups mostly includes Canadian specimens, with the dominance of one haplotype (Hap_4). Two Canadian haplotypes (Hap_7, Hap_8) are located in the network part connecting snails $S$. putris from Europe. Most of the 18 haplotypes revealed in our study are haplotypes of snails collected in Russia and Belarus. As in the case of COI gene, most haplotypes of snails from Leningrad Region and Kaliningrad Region fall into the same subgroup of CytB haplotypes. 


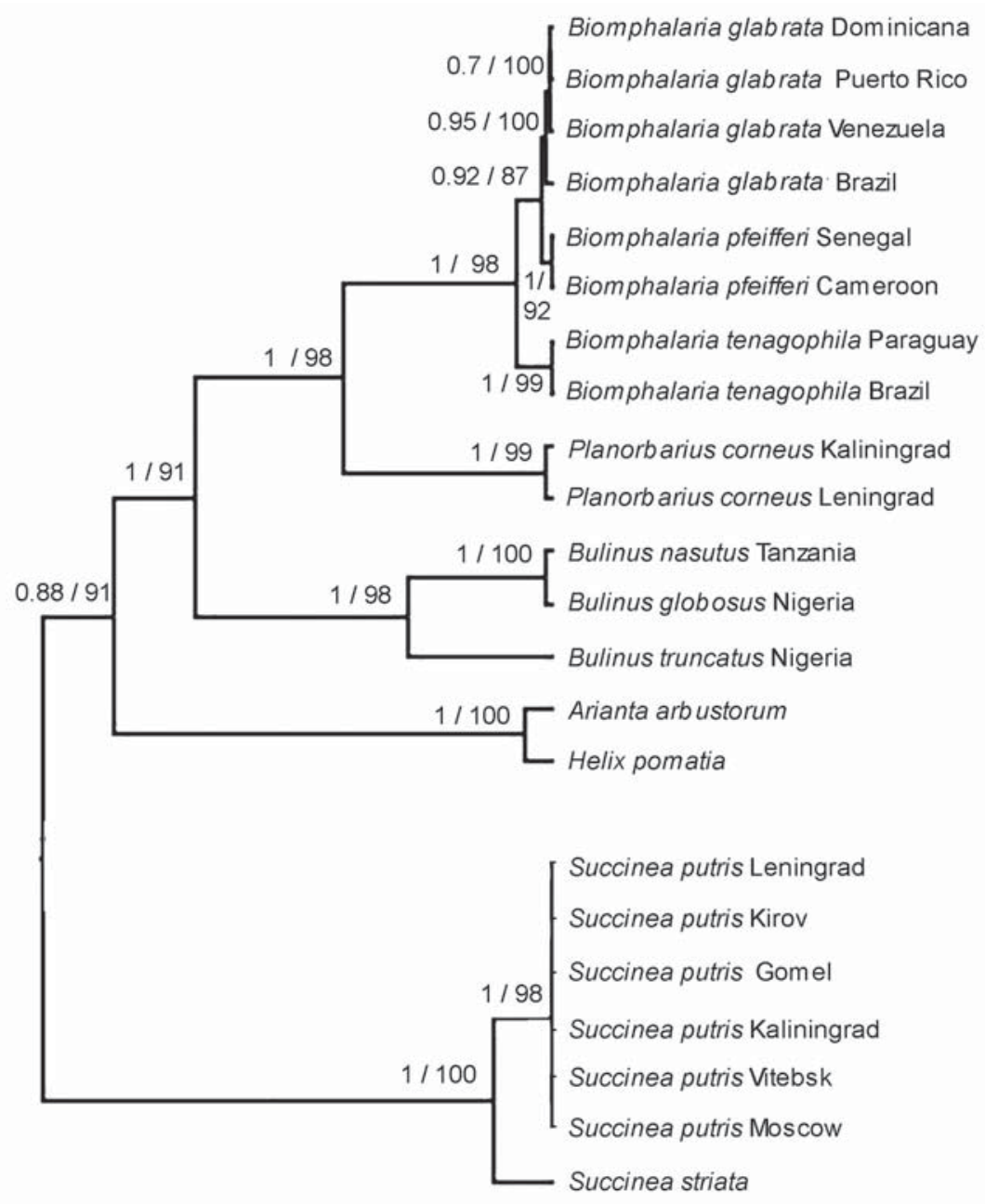

Fig. 8. The bayesian phylogenetic reconstruction based on ITS1-5.8S-ITS2 nucleotide sequences of rDNA (1390 bp) of Succinea putris. Tree obtained by the maximum likelihood method had the same topology. Number at the branch nodes indicates percentage bootstrap support for 1000 replicates for BI/ML. For sample codes and GenBank numbers see Appendix 1.

Рис. 8. Байесовская филогенетическая реконструкция на основе нуклеотидных последовательностей ITS1-5.8S-ITS2 участка рДНК (1390bp). Дерево, полученное методом максимального правдоподобия, имело такую же топологию. Обозначены бутстрепные поддержки для 1000 реплик для BI/ML. Номера образцов представлены в Приложении 1.

One haplotype of snails from Leningrad Region is an exception, being close to a haplotype described from Canada (Hap_9). Snails from Moscow Region were the most genotypically diverse. Snails from Vitebsk Region (Belarus) were monomorphic and represented by a single haplotype Hap_14. Average genetic distance between COI haplotypes in the studied samples was 0.009 (Appendix 3), with the French sample being an outlier (average genetic distance making up 0.053).

The results of phylogenetic reconstructions confirmed the trends in the distribution of haplotypes revealed in the haplotype networks. The specimen from France formed a separate clade (Figs 9, 10). 


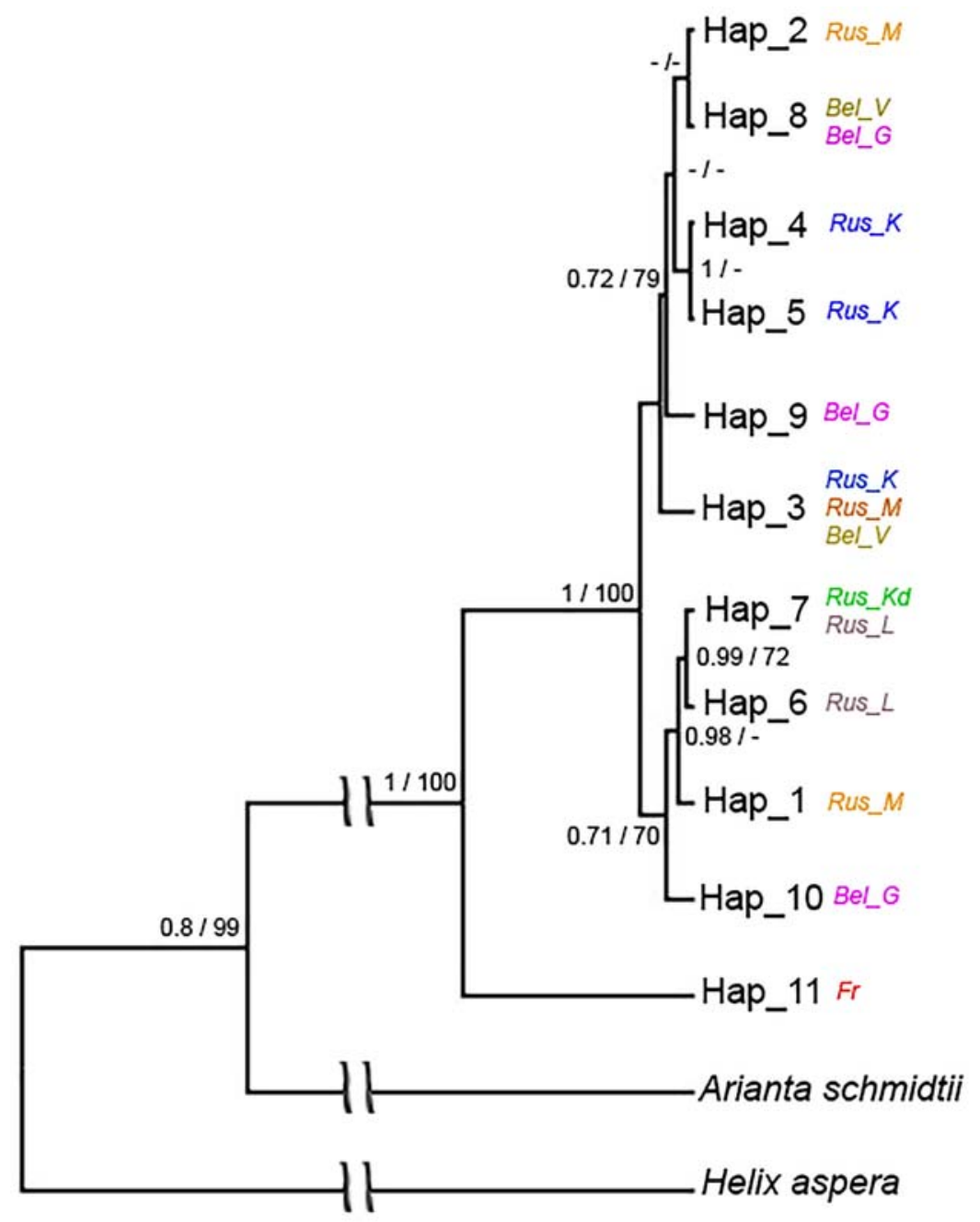

Fig. 9. The Bayesian phylogenetic reconstruction based on nucleotide sequences of haplotypes of Succinea putris CytB gene fragment. Tree obtained by the maximum likelihood method had the same topology. Number at the branch nodes indicates percentage bootstrap support for 1000 replicates for BI/ML. Hap_1Hap11-haplotypes CytB gene of Succinea putris. The regions where haplotypes were described are designated. For sample codes and GenBank numbers see Appendix 1.

Рис. 9. Байесовская филогенетическая реконструкция на основе нуклеотидных последовательностей участка гена CytB моллюска Succinea putris. Дерево, полученное методом максимального правдоподобия, имело такую же топологию. Обозначены бутстрепные поддержки для 1000 реплик для BI/ML. Hap_1-Нар11-гаплотипы гена CуtB моллюска Succinea putris. Номера образцов представлены в Приложении 1.

\section{Discussion}

Morphological analysis of snails $S$. putris collected in Kirovsk, Leningrad and Moscow Regions of Russia and in Vitebsk and Gomel Regions of Belarus did not reveal any statisti- cally significant differences between them. Snails from Vitebsk population were somewhat different in the shell index (Table 1). Some snails from Gomel population had the most pigmented surface epithelium (Fig. 1). However, these differences agree with the species description of 


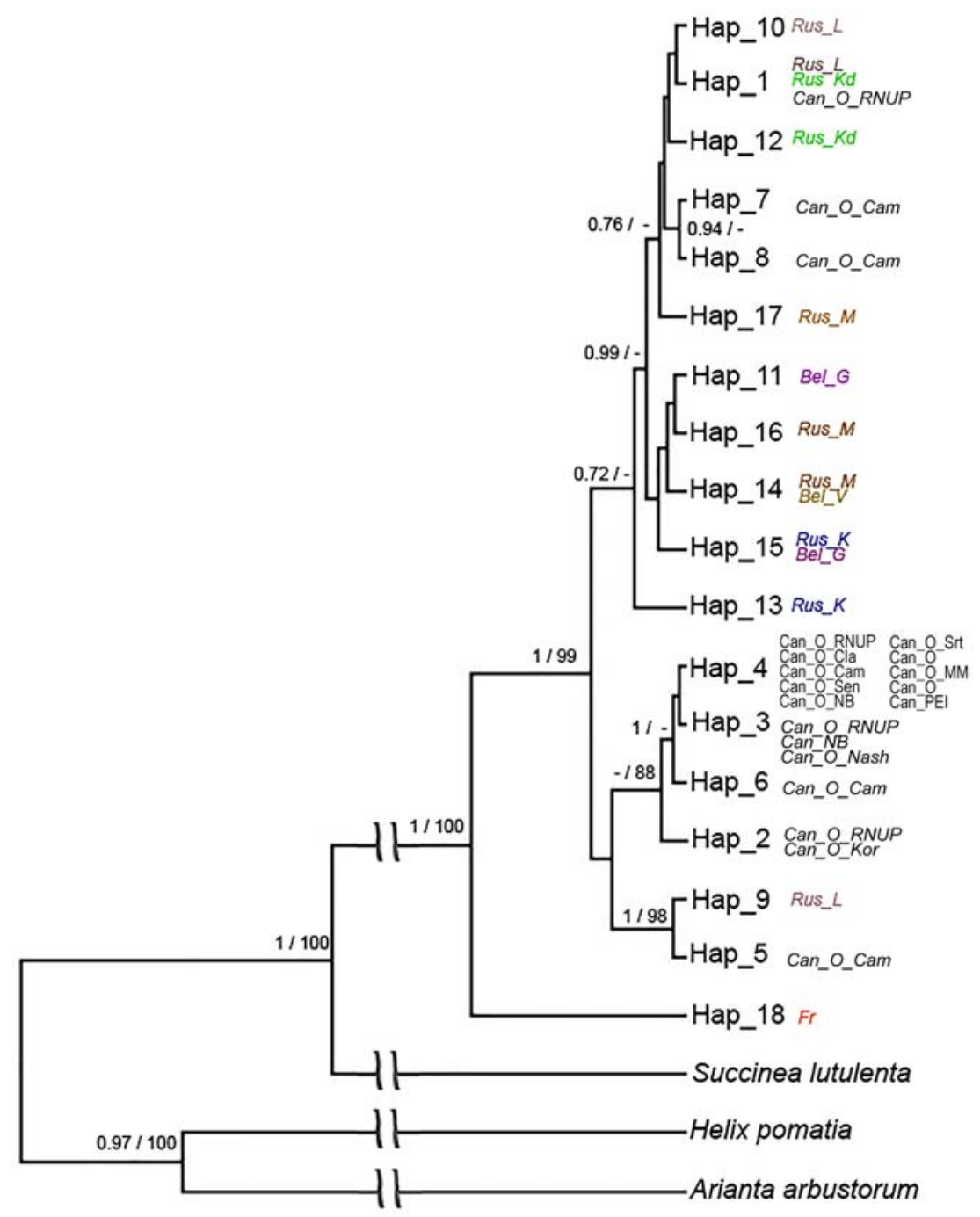

Fig. 10. The Bayesian phylogenetic reconstruction based on nucleotide sequences of haplotypes of Succinea putris COI gene fragment. Tree obtained by the maximum likelihood method had the same topology. Number at the branch nodes indicates percentage bootstrap support for 1000 replicates for BI/ML. Hap 1Hap18-haplotypes COI gene of Succinea putris. The regions where haplotypes were described are designated. For sample codes and GenBank numbers see Appendix 1.

Рис. 10. Байесовская филогенетическая реконструкция на основе нуклеотидных последовательностей участка гена COI моллюска Succinea putris. Дерево, полученное методом максимального правдоподобия, имело такую же топологию. Обозначены бутстрепные поддержки для 1000 реплик для BI/ML. Hap_1-Нар18-гаплотипы гена COI моллюска Succinea putris. Номера образцов представлены в Приложении 1.

snails $S$. putris based on morphological characters (Patterson, 1971; Schileyko, Likharev, 1986). Such characters as the structure of the jaw, the radula and the reproductive system did not differ in snails from different samples.
For genotyping S. putris we used rDNA fragments and fragments of two mitochondrial genes, COI and CytB. The data on each sequence were analysed separately. We did not perform a multigene analysis because no infor- 
mation about the nucleotide sequences of the studied genome regions of $S$. putris was available in the databases. Moreover, there are no such data for most pulmonates from closely related genera and families.

Genotypic analysis showed that snails from different regions of Russia and Belarus were completely identical by the studied rDNA region. Intraspecies variability by internal transcribed spacers is common in animals, which makes these genome areas convenient for revealing differences within species (Coleman, Mai, 1997; Coleman, 2003; Young, Coleman, 2004 ; etc.) Other species of pulmonate molluscs, in which these genome region has been studied, are characterised by a slight intraspecies variability of ITS. For instance, species from the genera Biomphalaria, Planorbarius and Bulinus, which were used as outgroups, also demonstrated a high intraspecies homology of this genome region: their ITS1-5.8S-ITS2 nucleotide sequences were identical or showed a 99\% homology. In particular, genetic distance between snails $P$. corneus from the Kaliningrad Region and the Leningrad Region is only ca. 0.03\% (Prokhorova et al., 2014). The homology of this genome region for different strains of Biomphalaria glabrata makes up from 99.1 to 100\% (Zhang et al., 2018).

The studied rDNA region has been fully genotyped only in one other Succinea species, $S$. striata Krauss, 1848. It forms a common clade with $S$. putris on the phylogenetic reconstruction. The homology of the nucleotide sequences of $S$. putris and $S$. striata made up $89.5 \%$, the greatest differences being associated with ITS2 region, where the homology was 83.5\% (Wade et al., 2006).

Because of its intraspecies conservativeness, ITS genome fragment can be used for species identification of $S$. putris. Secondary structures of ITS2 transcripts are used to visualise significant differences in the nucleotide sequences. Their general structure was different in S. putris and S. striata. The differences in the secondary structure of ITS transcripts are used, alongside with other characters, to determine the divergence between species from different taxa (Schultz et al., 2005). Our study confirmed that this character is also applicable to the genus Succinea. Topological features of the ITS2 transcript can be used as an additional character for species identification of $S$. putris.

Mitochondrial DNA of pulmonate molluscs is thought to be variable, and genetic interspecies and intraspecies distances are larger than in other animal groups (Thomaz et al., 1996; Pinceel et al., 2005). Our analysis of mitochondrial markers of S. putris also showed a high genotypic diversity (Table 2). We found that the studied snails had 9 COI haplotypes and 10 CytB haplotypes. Snails from Moscow Region had the highest diversity of haplotypes (Appendices 2, 3 ), while snails from Kaliningrad Region and Vitebsk Region were the least diverse in this respect. The least nucleotide diversity of the mitochondrial genes under study was noted in Gomel Region, while the highest diversity was noted in Leningrad Region and Kirovsk Region. Snails from Europe form two haplogroups in the $\mathrm{CytB}$ and COI haplotype networks. One of the groups (in both networks) comprises snails from Leningrad Region and Kaliningrad Region. The distribution of haplotypes of snails from other regions does not show any distinct tendency: each of the population has both unique haplotypes and haplotypes shared with snails from other regions.

Interestingly, one of the COI haplotypes belonging to a snail from Leningrad Region is close to one of the Canadian haplotypes (Hap_9). The most plausible cause of this phenomenon is an accidental import of molluscs from one continent to another (Anistratenko, 1991; Son, 2007; Haase et al., 2010, etc.). In general, the haplotypic diversity of European specimens is higher than that of Canadian ones even though the Canadian sampling was much more extensive.

Despite the diversity of COI and CytB haplotypes, genetic distances between them are not very large (Tables 3,4). The indices of intraspecies variability are comparable with those of another species of amber snails studied in this respect, Succinea caduca, in which the average genetic distance between populations is 0.028 (Holland, Cowie, 2007). The average genetic 
distance between samples of $S$. putris and samples of congeneric species $S$. lumbaris, S. lutulenta, $S$. canella and $S$. caduca by COI gene made up $0.177 \pm 0.01$. Thus, the differences found in our study fall within the range of variability within the species.

The mitochondrial genome of S. purtis from France available in GenBank (Appendix 1) deserves special mention: both $\mathrm{COI}$ and $\mathrm{CytB}$ haplotypes of this specimen are outliers (28 nucleotide substitutions in COI gene and 27 substitutions in CytB gene). Average genetic distance to other haplotypes made up 0.059, which might correspond to differences between species. Unfortunately, no morphological description and no data on other genome regions of the French snail were reported (White et al., 2011). Therefore, we cannot be sure that its species was identified correctly.

The results of the analysis of genotypic polymorphism with the use of mitochondrial markers are confirmed by the phylogenetic reconstructions (Figs 8 and 9).

Comparison of our data with the results of genotyping of Succinea snails from Canada (Telfer et al., 2015) confirmed the similarity of all the snails by mitochondrial genetic markers. This indicates that the studied snails $S$. putris are genetically homogeneous, the homogeneity probably underlying a low variability of morphological characters in this species.

Acknowledgements. This investigation was financially supported by the Russian Foundation for Basic Research grant 18-34-00522 mol a and 1904-00384. We thank Mr. Tobin Auber for his assistance in translating the manuscript into English.

\section{References}

Adachi J., Hasegawa M. 1996. Model of amino acid substitution in proteins encoded by mitochondrial DNA // J. Mol. Evol. Vol.42. P.459-468.

Anistratenko V.V. 1991. [Molluscs of Hydrobia group sensu lato of the Black and the Azov Sea] // Bull. Moskovskogo Obshchestva Ispytatelei Prirody. Otd. biol. Vol.96. No.6. P.73-81 [in Russian].

Ataev G.L., Tokmakova A.S. 2015. [Seasonal changes in the biology of Leucochloridium paradoxum (Trematoda, Leucochloridiomorphidae)] // Parazitologiya. Vol.49. No.3. P.200-207 [in Russian].

Ataev G.L., Zhukova A.A., Tokmakova A.S., Prokhorova E.E. 2016. Multiple infection of amber snails Succinea putris with sporocysts of Leucochloridium spp. (Trematoda) // Parasitol. Res. Vol.115. No.8. P. 3203-3208.

Bouckaert R., Vaughan T.G., Barido-Sottani J., Duchêne S., Fourment M., Gavryushkina A., Heled J., Jones G., Kühnert D., De Maio N., Matschiner M., Mendes F.K., Müller N.F., Ogilvie H.A., du Plessis L., Popinga A., Rambaut A., Rasmussen D., Siveroni I., Suchard M.A., Wu C.H., Xie D., Zhang C., Stadler T., Drummond A.J. 2019. BEAST 2.5: An advanced software platform for Bayesian evolutionary analysis // PLoS Comput Biol. Vol.15. No.4: e1006650. P.1-28.

Coleman A.W. 2003. ITS2 is a double-edged tool for eukaryote evolutionary comparisons // Trends Genet. Vol.19. P.370-375.

Coleman A.W., Mai J.C. 1997. Ribosomal DNA ITS-1 and ITS-2 sequence comparisons as a tool for predicting genetic relatedness // J. Mol. Evol. Vol.45. P.168177.

Darriba D., Taboada G.L., Doallo R., Posada D. 2012. jModelTest 2: more models, new heuristics and parallel computing // Nat. Methods. Vol.9. No.8. P.772.

Draparnaud J. 1801. Tableau des mollusques terrestres et fluviatiles de la France. Renaud. Montpellier. 116 p.

Enigk R. 1932. Leucochloridium paradoxum in Succinea oblonga // Sitzungsberichte der Gesellschaft naturforschender Freunde zu Berlin. S.442-443.

Felsenstein J. 1985. Confidence limits on phylogenies: An approach using the bootstrap // Evolution. Vol.39. P.783-791.

Gower C. 1936. New sporocyst of Leucochloridium from Louisiana // J. Parasitol. Vol.22. No.4. P.375-378.

Haase M., Naser M.D., Wilke T. 2010. Ecrobia grimmi in brackish Lake Sawa, Iraq: indirect evidence for longdistance dispersal of hydrobiid gastropods (Caenogastropoda: Rissooidea) by birds // J. Molluscan Stud. Vol.76. P.101-105.

Hall T.A. 1999. BioEdit: a user-friendly biological sequence alignment editor and analysis program for Windows 95/98/NT // Nucl. Acids. Symp. Ser.41. P.95-98.

Hasegawa M., Kishino H., Yano T. 1985. Dating the human-ape split by a molecular clock of mitochondrial DNA // J. Mol. Evol. Vol.22. P.160-174.

Heneberg P., Sitko J., Bizos J. 2016. Molecular and comparative morphological analysis of central European parasitic flatworms of the superfamily Brachylaimoidea Allison, 1943 (Trematoda: Plagiorchiida) // Parasitology. Vol.143. No.4. P.455-474.

Holland B.S., Cowie R.H. 2007. A geographic mosaic of passive dispersal: population structure in the endemic Hawaiian amber snail Succinea caduca (Mighels, 1845) // Mol. Ecol. Vol.16. No.12. P.2422-2435.

Jeffreys J.G. 1833. A synopsis of the Testaceous Pneumonobranchous Mollusca of Great Britain // Trans. Linn. Soc. Lond. Vol.16. P.323-392.

Kimura M. 1980. A simple method for estimating evolutionary rate of base substitutions through comparative studies of nucleotide sequences // J. Mol. Evol. Vol.16. P.111-120.

Kumar S., Stecher G., Tamura K. 2016. MEGA7: Molecular Evolutionary Genetics Analysis version 7.0 for bigger datasets // Mol. Biol. Evol. Vol.33. P.1870-1874.

Leigh J.W., Bryant D. 2015. PopART: Full-feature software for haplotype network construction // Methods Ecol. Evol. Vol.6. No.9. P.1110-1116. 
Lewis P.D. 1974. Helminths of terrestrial molluscs in Nebraska. II. Life Cycle of Leucochloridium variae McIntosh, 1932 (Digenea: Leucochloridiidae) // J. Parasitol. Vol.60. No.2. P.251-255.

Nakao M., Sasaki M., Waki T., Iwaki T., Morii Y., Yanagida K., Watanabe M., Tsuchitani Y., Saito T., Asakawa M. 2019. Distribution records of three species of Leucochloridium (Trematoda: Leucochloridiidae) in Japan, with comments on their microtaxonomy and ecology // Parasitol. Int. Vol.72. No.101936. P.1-12.

Nei M., Kumar S. 2000. Molecular Evolution and Phylogenetics. New York: Oxford University Press. 348 p.

Patterson C.M. 1971. Taxonomic studies of the land snail family Succineidae // Malacological Rev. Vol.4. P.131202.

Pinceel J., Jordaens K., Backeljau T. 2005. Extreme mtDNA divergences in a terrestrial slug (Gastropoda, Pulmonata, Arionidae): accelerated evolution, allopatric divergence and secondary contact // J. Evol. Biol. Vol.18. No.5. P.1264-1280.

Pojmanska T. 1978. Life cycle of Leucochloridium vogtianum Baudon, 1881 (L. phragmitophila) Byhovskaja-Pavlovskaja et Dubinina, 1951 in parte) (Trematoda, Lecochloridiidae) // Acta Parasitol. Pol. Vol.25. No.14. P.129-134.

Prokhorova E.E., Zhemchuzhnikova E.A., Ataev G.L. 2015. Analysis of ITS1 and ITS2 of ribosomal DNA in populations of Planorbarius corneus snails (Gastropoda) from the Leningradand Kaliningrad oblasts of Russia // Contemp. Probl. Ecol. Vol.8. No.6. P.729-734.

Prokhorova E.E., Zhukova A.A., Tsymbalenko N.V., Lopatina O.D., Ataev G.L. 2017. [RAPD markers for species identification of trematodes from the genus Leucochloridium] // Parazitologiya. Vol.51. No.4. P.339-344 [in Russian. with English summary].

Prokhorova E.E., Zhemchuzhnikova E.A., Ataev G.L. 2014. [The use of RAPD-analysis for studying genetic populational variability of molluscs Planorbarius corneus (Gastropoda, Pulmonata)] // Izvestiya Rossiiskogo gosudarstvennogo pedagogicheskogo universiteta im. A.I. Gertsena. No.168. P.62-68 [in Russian, with English summary].

Rozas J., Ferrer-Mata A., Sánchez-DelBarrio J.C., GuiraoRico S., Librado P., Ramos-Onsins S.E., SánchezGracia A. 2017. DnaSP 6: DNA Sequence Polymorphism Analysis of Large Data Sets // Mol. Biol. Evol. Vol.34. No.12. P.3299-3302.

Rzhetsky A., Nei M. 1992. A simple method for estimating and testing minimum evolution trees // Mol. Biol. Evol. Vol.9. P.945-967.

Saitou N., Nei M. 1987. The neighbor-joining method: A new method for reconstructing phylogenetic trees // Mol. Biol. Evol. Vol.4. P.406-425.

Sambrook J., Russell D.W. 2001. Molecular clonining: a laboratory manual. $3^{\text {rd }}$ ed. Cold Spring Harbor: Cold Spring Harbor Press. 2100 p.

Schileyko A.A., Likharev I.M. 1986. [Land snails of the family of amber snails (Succineidae) in the fauna of the USSR]// Sbornik Trudov Zoologicheskogo Muzeya MGU. Vol.24. P.197-238 [in Russian].

Schultz J., Maisel S., Gerlach D., Müller T., Wolf M. 2005. A common core of secondary structure of the internal transcribed spacer 2 (ITS2) throughout the Eukaryota // RNA. Vol.11. No.4. P.361-364.

Son M.O. 2007. [Invading molluscs in fresh and brackish waters of northern Black Sea Region] Odessa: Druk. 132 p. [In Russian]

Telfer A., Young M., Quinn J., Perez K., Sobel C., Sones J., Levesque-Beaudin V., Derbyshire R., FernandezTriana J., Rougerie R., Thevanayagam A., Boskovic A., Borisenko A., Cadel A., Brown A., Pages A., Castillo A., Nicolai A., Glenn Mockford B., Bukowski B., Wilson B., Trojahn B., Lacroix C., Brimblecombe C., Hay C., Ho C., Steinke C., Warne C., Garrido Cortes C., Engelking D., Wright D., Lijtmaer D., Gascoigne D., Hernandez Martich D., Morningstar D., Neumann D., Steinke D., Marco DeBruin D., Dobias D., Sears E., Richard E., Damstra E., Zakharov E., Laberge F., Collins G., Blagoev G., Grainge G., Ansell G., Meredith G., Hogg I., McKeown J., Topan J., Bracey J., Guenther J., Sills-Gilligan J., Addesi J., Persi J., Layton K., D’Souza K., Dorji K., Grundy K., Nghidinwa K., Ronnenberg K., Lee K., Xie L., Lu L., Penev L., Gonzalez M., Rosati M., Kekkonen M., Kuzmina M., Iskandar M., Mutanen M., Fatahi M., Pentinsaari M., Bauman M., Nikolova N., Ivanova N., Jones N., Weerasuriya N., Monkhouse N., Lavinia P., Jannetta P., Hanisch P., McMullin R., Ojeda Flores R., Mouttet R., Vender R., Labbee R., Forsyth R., Lauder R., Dickson R., Kroft R., Miller S., MacDonald S., Panthi S., Pedersen S., Sobek-Swant S., Naik S., Lipinskaya T., Eagalle T., Decaëns T., Kosuth T., Braukmann T., Woodcock T., Roslin T., Zammit T., Campbell V., Dinca V., Peneva V., Hebert P., deWaard J. 2015. Biodiversity inventories in high gear: DNA barcoding facilitates a rapid biotic survey of a temperate nature reserve // Biodivers. Data J. Vol.3: 6313.

Thomaz D., Guiller A., Clarke B. 1996. Extreme divergence of mitochondrial DNA within species of pulmonate land snails // Proc. Biol. Sci. Vol.263. P.363-368.

White T.R., Conrad M.M., Tseng R., Balayan S., Golding R., de Frias Martins A.M., Dayrat B.A. 2011. Ten new complete mitochondrial genomes of pulmonates (Mollusca: Gastropoda) and their impact on phylogenetic relationships // BMC Evol. Biol. Vol.11. No.295. P.115.

Wade M.C., Mordan B.F., Naggs F. 2006. Evolutionary relationships among the Pulmonate land snails and slugs (Pulmonata, Stylommatophora) // Biol. J. Linn. Soc. Lond. Vol.87. No.4. P.593-610.

Young I., Coleman A.W. 2004. The advantages of the ITS2 region of the nuclear rDNA cistron for analysis of phylogenetic relationships of insects: a Drosophila example// Mol. Phylogenet. Evol. Vol.30. No.1.P.236242.

Zhang S.M., Bu L., Laidemitt M.R., Lu L., Mutuku M.W., Mkoji G.M., Loker E.S. 2018. Complete mitochondrial and rDNA complex sequences of important vector species of Biomphalaria, obligatory hosts of the human-infecting blood fluke, Schistosoma mansoni // Sci. Rep. Vol.8. No.7341. P.1-10.

Responsible editor E.N. Temereva 